\title{
UPAYA MENINGKATKAN HASIL BELAJAR OPERASI BILANGAN BULAT MELALUI MEDIA KONKRET DI SDN 4 MUARAKUANG
}

\author{
Erna Sari \\ Guru SD Negeri 4 Muarakuang \\ Desa Muarakuang Kab. Ogan Ilir Sumsel \\ Sur-el: ernasari1963@gmail.com
}

Article info

Article history:

Received: 10/05/2019

Revised : 11/05/2019

Accepted: 10/06/2019

Keywords:

media, concrete,

operations, integers

Kata Kunci: media, konkret, operasi, bilangan bulat

\section{A B S T R A C T}

The problem in this study is whether the use and application of concrete media can iprove students' skills in integer operations in class V of Muarakuang 04 Elementary School? The purpose of this study was to determine the improvement of student learning outcomes about integer operations through concrete media. Of the 24 students, there were 17 students who successfully achieved the KKM score. In addition, there are 7 students who have not yet reached KKM. This means that the completeness achieved in Cycle I is $71 \%$. In cycle II, the researcher made a decision to complete the research action and did not need to continue the research at the Cycle III stage due to the fulfillment of $86 \%$ KKM. The conclusion of the results of this study is that the application of concrete media can improve learning outcomes about integer operations in Class V students of SDN 4 Muara Kuang.

Rumusan masalah pada penelitian ini adalah Apakah penggunaandan penerapan media konkret dapat meningkatkan keterampilan siswa dalam operasi bilangan bulat kelas V SD Negeri 04 Muarakuang? Tujuan penulisan penelitian ini untuk mengetahui peningkatan hasil belajar siswa tentang operasi bilangan bulat melalui media konkret. Hasil penelitian ini diharapkan dapat memberikan konstribusi bagi semua pihak, antara lain bagi Guru, siswa, dan sekolah. Dari 24 siswa, ada 17 orang siswa yang berhasil mencapai nilai KKM. Selain itu, terdapat 7 orang siswa yang belum mencapai KKM. Artinya ketuntasan yang dicapai pada Siklus I adalah $71 \%$. Pada siklus II, peneliti mengambil keputusan untuk menyelesaikan tindakan penelitian dan tidak perlu melanjutkan penelitian pada tahap Siklus III dikarenakan pemenuhan 86\% KKM. Kesimpulan dari hasil penelitian ini adalah Penerapan media konkret dapat meningkatkan hasil belajar tentang operasi bilangan bulat pada siswa Kelas V SDN 4 Muara Kuang. 


\section{JURNAL ILMIAH \\ BINA EDUKASI \\ ISSN 1979-8598 e-ISSN: 2655-8378 \\ http://journal.binadarma.ac.id/index.php/jurnalbinaedukasi \\ Vol. 12, No. 1, Juni 2019, 01-15}

\section{PENDAHULUAN}

Bilangan erat hubungannya dengan kehidupan manusia. Manusia menggunakan bilangan dalam berbagai aspek kehidupannya. Bilangan itu bukan simbol atau lambang, dan bukan pula lambang bilangan. Bilangan itu adalah sesuatu yang bersifat abstrak yang memberi keterangan mengenai banyaknya anggota suatu himpunan. Menurut Samidi dan Puspitasari (2004), bilangan terdiri dari bilangan asli disebut bilangan positif, bilangan nol, dan lawan bilangan asli disebut bilangan bulat negatif.

Pengertian bilangan bulat menurut pendapat Novikasari dan Mutijah (2010) yaitu merupakan perluasan bilangan cacah. Gabungan dari himpunan semua bilangan cacah dan himpunan semua bilangan bulat negatif disebut semua bilangan bulat.

Salah satu permasalahan yang menyangkut pengelolaan proses belajar mengajar mata pelajaran matematika di SD adalah kurangnya pengetahuan bagi guru SD, serta terbatasnya dana dan sarana tentang bagaimana cara membuat dan menggunakan media/alat peraga dalam pembelajaran matematika, khususnya materi pada bilangan bulat. Di sisi lain, pentingnya media/alat peraga dalam pembelajaran matematika telah diakui oleh semua jajaran pengelola pendidikan dan para ahli pendidikan. Berdasarkan survei awal penulis terlihat rendahnya ketuntasan belajar yang dilaksanakan oleh pendidik. Untuk itu, diperlukan strategi khusus untuk meningkatkan keberhasilan kegiatan belajar-mengajar.

Kompetensi guru dalam pelaksanaan interaksi belajar maupun mengajar mempunyai indikator, mampu membuka pelajaran, mampu menyajikan materi, mampu menggunakan media/strategi, mampu menggunakan media/ alat peraga, mampu menggunakan bahasa yang komutatif, mampu memotivasi siswa, mampu mengorganisasi kegiatan, mampu menyimpulkan pelajaran, mampu memberikan umpan balik, mampu melaksanakan penilaian, dan mampu menggunakan waktu (Departemen Pendidikan Nasional, 2004).

Menurut Pujiati (2004), untuk memahami pengetahuan yang baru, maka diperlukan tahapan-tahapan yang runtut, yaitu: enactive, ikonik, dan simbolik. Tahap enactive, yaitu tahap belajar dengan memanipulasi benda atau objek yang kongkret, tahap ikonik, yaitu tahap belajar dengan menggunakan gambar, dan tahap simbolik, yaitu tahap belajar melalui manipulasi lambang atau simbol.

Berdasarkan pada uraian di atas, siswa pada usia sekolah dasar dalam memahami konsep-konsep matematika masih sangat memerlukan kegiatan-kegiatan yang berhubungan dengan benda nyata (pengalaman-pengalaman konkret) yang dapat diterima akal mereka. 


\section{JURNAL ILMIAH \\ BINA EDUKASI \\ ISSN 1979-8598 e-ISSN: 2655-8378 \\ http://journal.binadarma.ac.id/index.php/jurnalbinaedukasi \\ Vol. 12, No. 1, Juni 2019, 01-15}

Menurut Winataputra (2005), media konkret adalah segala sesuatu yang nyata dan dapat digunakan untuk menyalurkan pesan dari pengirim ke penerima sehingga dapat merangsang pikiran, perasaan, perhatian dan minat siswa sehingga proses pembelajaran dapat berjalan lebih efektif dan efesien menuju pada tercapainya tujuan yang diharapkan.

Dalam penelitian tindakan kelas ini, peneliti mencoba mengetengahkan salah satu bentuk pembelajaran aktif, kreatif, efektif, dan menyenangkan. Dalam penyampaian pembelajaran ini, peneliti menggunakan media/alat peraga dengan media konkret dalam operasi bilangan bulat kelas V SDN 04 Muarakuang.

\section{METODOLOGI PENELITIAN}

Penelitian ini adalah penelitian tindakan kelas yang di dalamnya terdapat empat tahap kegiatan yaitu perencanaan, pelaksanaan tindakan, observasi dan refleksi (Kurt Lewis dalam Rochiati, 2006). Subjek dalam penelitian ini adalah siswa kelas V SD Negeri 04 Muarakuang.

Menurut Sanjaya (2011), instrumen yang digunakan dalam kepentingan penelitian tindakan kelas ini seperti Rencana Pelaksanaan Pembelajaran (RPP), Lembar Kerja Siswa (LKS), Lembar Kerja Kelompok (LKK), lembar observasi, wawacara, catatan lapangan, dan dokumentasi.

Pengumpulan data menggunakan lembar observasi dan dokumentasi. Lembar observasi ini berguna untuk pengamatan (pengambilan data) dalam kemampuan berpikir kritis siswa dalam proses pembelajaran dan untuk pengamatan kegiatan aktivitas guru selama proses pembelajaran. Selain itu, lembar observasi berguna untuk mengetahui kesesuaian pelaksanaan tindakan dengan rencana pelaksanaan pembelajaran (RPP) yang telah disusun sebelumnya.

Dokumentasi bisa berbentuk tulisan, gambar, atau karya-karya monumental dari seseorang (Sugiyono dalam Iskandar dan Narsim, 2015). Dokumentasi foto merupakan instrumen nontes yang cukup penting, yaitu sebagai bukti kegiatan selama pembelajaran berlangsung, baik kegiatan yang dilaksanakan selama penelitian.

Menurut Arikunto (2010), validitas adalah suatu ukuran yang menunjukkan tingkatan kevalidan atau kesahihan sebuah instrumen. Suatu instrumen dinyatakan valid apabila mampu mengukur apa yang diinginkan dan dapat mengungkap data dari variabel yang diteliti secara tepat. 


\section{JURNAL ILMIAH \\ BINA EDUKASI \\ ISSN 1979-8598 e-ISSN: 2655-8378 \\ http://journal.binadarma.ac.id/index.php/jurnalbinaedukasi \\ Vol. 12, No. 1, Juni 2019, 01-15}

Menurut Sugiyono (2010), validitas merupakan derajat ketepatan antara data yang terjadi pada objek penelitian dengan data yang dapat dilaporkan oleh peneliti. Suatu data dikatakan valid apabila tidak ada perbedaan antara data yang dilaporkan peneliti dengan data yang sesungguhnya.

Analisis data dalam penelitian ini dilakukan pada saat pengumpulan data berlangsung dan setelah pengumpulan data dalam periode tertentu. menurut Miles dan Huberman dalam Sugiyono (2013), aktivitas dalam analisis data ini meliputi data reduction, display, dan conclusion drawing/verification.

Indikator keberhasilan penelitian ini adalah pemahaman matematika siswa berdasarkan tes akhir siklus dikatakan meningkat apabila dalam proses pembelajaran terlihat adanya peningkatan jumlah siswa yang tuntas pemahaman dari siklus 1 ke siklus berikutnya dengan kriteria $75 \%$ dari total siswa dalam kelas, tuntas minimal pada tingkat 3 atau memuaskan dengan sedikit kekurangan. Aktivitas belajar siswa dikatakan meningkat apabila dalam proses pembelajaran terlihat adanya peningkatan aktivitas belajar siswa dari minimum aktivitas belajar siswa berkategori aktif atau baik. Presentase hasil belajar siswa mengalami peningkatan dari siklus 1 ke siklus berikutnya dengan Kriteria Ketuntasan Minimal (KKM) sebesar 60.

\section{HASIL DAN PEMBAHASAN}

\subsection{Hasil Penelitian}

\subsubsection{Hasil Tes Awal}

Pelaksanaan tes awal dilakukan pada hari Senin, tanggal 14 Februari 2019 selama 1 jam pembelajaran atau 35 menit. Dimulai dari pukul 07.30 sampai dengan 08.05 WIB. Tes awal ini dilakukan untuk mengetahui kemampuan siswa kelas V SD Negeri 04 Muarakuang dalam pembelajaran Matematika tentang operasi bilangan bulat dengan menggunakan media konkret. Dari pelaksanaan tes awal ini, akan diperoleh bahan masukan sebagai bahan dasar pertimbangan dalam menyusun perencanaan, tindakan, observasi dan refleksi siklus I.

Berdasarkan data yang sudah dikelola, total siswa ada 24 siswa, ada 11 orang siswa yang berhasil mencapai nilai KKM. Selain itu, terdapat 13 orang siswa yang belum mencapai KKM. Artinya ketuntasan yang dicapai pada tes awal adalah $46 \%$. Hal ini tentunya sangat di bawah standar yang akan dicapai. 
Hasil nilai tes awal berdasarkan nilai tertinggi, terendah dan rata-rata diketahui pada tabel berikut :

Tabel 1. Nilai Hasil Tes Awal tentang Operasi Bilangan Bulat

\begin{tabular}{cccccc}
\hline No & Nilai & Frekuensi & Tertinggi & Terendah & Rata-Rata \\
\hline 1 & $90-100$ & 0 & & & \\
2 & $60-89$ & 11 & & & \\
3 & $40-59$ & 13 & 70 & 40 & \\
4 & $20-39$ & 0 & & & \\
5 & $0-19$ & 0 & $\mathbf{2 4}$ & & \\
& Jumlah & &
\end{tabular}

Dari tabel di atas, diketahui bahwa nilai tertinggi dari tes awal adalah 70 dan nilai terendah adalah 40 dengan rata-rata 56. Dari 24 siswa, 11 orang siswa memperoleh nilai pada range 60 - 89, dan 13 siswa memperoleh nilai pada range 40-59.

\subsubsection{Hasil Penelitian Siklus I}

\section{a. Deskripsi Tindakan dan Pengamatan Siklus I Pembelajaran Ke-I}

Pelaksanaan ke-1 pembelajaran Matematika tentang operasi bilangan bulat dengan menggunakan media konkret dilakukan pada hari Senin, tanggal 18 Februari 2019, selama 3 jam pelajaran (3 x 35 menit). Kegiatan ini dimulai pukul 07.30 WIB sampai pukul 09.15 WIB. Pada saat pelaksanaan tindakan Siklus I ini, jumlah siswa kelas V yang hadir berjumlah 24 orang.

Kolaborator dalam penelitian ini adalah Ibu Purwiratnawati, S.Pd.SD. Setelah jam pelajaran dimulai, peneliti dalam hal ini selaku guru, membariskan siswa di depan pintu kelas, dan secara tertib masuk ke dalam kelas setelah bersalaman dengan guru. Setelah seluruh siswa masuk ke dalam kelas, guru menempati kursi dan meja guru yang berada di depan kelas sedangkan rekan kolaborator mengambil tempat di belakang. Kemudian, secara tertib, siswa membaca doa dan ayat-ayat pendek yang telah mereka hafalkan dan telah menjadi rutinitas. Setelah itu, guru menunjuk salah satu siswa maju ke depan kelas untuk menjadi dirijen/pemandu lagu. Guru bersama siswa menyanyikan lagu wajib Indonesia Raya, dan lagu Bangun Pemuda Pemudi. Setelah siswa pemandu lagu kembali ke tempat duduknya, guru kemudian mengecek kehadiran siswa satu per satu. Hari itu semua siswa hadir. Di akhir kegiatan absensi, guru memberikan sedikit nasihat tentang kenakalan remaja yang patut diwaspadai.

Setelah itu, guru menginstruksikan kepada siswa untuk membentuk kelompok yang terdiri dari 4 siswa per kelompoknya. Di bawah pengawasan guru, siswa secara mandiri 


\section{JURNAL ILMIAH}

BINA EDUKASI

ISSN 1979-8598 e-ISSN: 2655-8378

http://journal.binadarma.ac.id/index.php/jurnalbinaedukasi

Vol. 12, No. 1, Juni 2019, 01-15

membentuk kelompok berdasarkan posisi tempat duduk terdekat. Setelah mengondisikan kelas, memastikan kesiapan siswa dan memberikan salam pembuka pembelajaran, guru dengan didampingi kolaborator menyampaikan tujuan pembelajaran pada hari ini yaitu setelah kegiatan belajar mengajar, siswa dapat memahami tentang operasi bilangan bulat dengan menggunakan media konkret.

Pada kegiatan siklus I pembelajaran I ini, tidak dilakukan tes.

\section{b. Deskripsi Tindakan dan Pengamatan Siklus I Pembelajaran Ke-II}

Kegiatan pelaksanaan ke-II pembelajaran Matematika tentang operasi bilangan bulat dengan menggunakan media konkret dilakukan pada hari Kamis, tanggal 21 Februari 2019 selama 3 jam pelajaran ( 3 x 35 menit). Kegiatan ini dimulai pukul 07.30 WIB sampai pukul 09.15 WIB. Pada saat pelaksanaan tindakan Siklus I ini, jumlah siswa kelas V yang hadir tetap berjumlah 24 orang. Artinya seluruh siswa hadir. Setelah jam pelajaran di mulai, peneliti dalam hal ini selaku guru, membariskan siswa di depan pintu kelas, dan secara tertib masuk ke dalam kelas setelah bersalaman dengan guru.

Setelah seluruh siswa masuk ke dalam kelas, guru menempati kursi dan meja guru yang berada di depan kelas sedangkan rekan sejawat mengambil tempat di belakang. Kemudian, secara tertib, siswa membaca doa dan ayat-ayat pendek yang telah mereka hafalkan dan telah menjadi rutinitas dalam kegiatan awal pembelajaran di kelas.

Berdasarkan data yang diperoleh bahwa dari 24 siswa, ada 17 orang siswa yang berhasil mencapai nilai KKM. Selain itu, terdapat 7 orang siswa yang belum mencapai KKM. Artinya ketuntasan yang dicapai pada Siklus I adalah $71 \%$.

Lebih lanjut, hasil nilai Siklus I berdasarkan nilai tertinggi, terendah dan rata-rata diketahui pada tabel berikut :

Tabel 2. Nilai Hasil Siklus I tentang Operasi Bilangan Bulat

\begin{tabular}{cccccc}
\hline No & Nilai & Frekuensi & Tertinggi & Terendah & Rata-Rata \\
\hline 1 & $90-100$ & 0 & & & \\
2 & $60-89$ & 17 & & & \\
3 & $40-59$ & 7 & 80 & 50 & \\
4 & $20-39$ & 0 & & & \\
5 & $0-19$ & 0 & $\mathbf{2 4}$ & & \\
& Jumlah & &
\end{tabular}




\section{JURNAL ILMIAH}

BINA EDUKASI

ISSN 1979-8598 e-ISSN: 2655-8378

http://journal.binadarma.ac.id/index.php/jurnalbinaedukasi

Vol. 12, No. 1, Juni 2019, 01-15

Dari tabel di atas, diketahui bahwa nilai tertinggi dari Siklus I adalah 80 dan nilai terendah adalah 50 dengan rata-rata 65 . Dari 24 siswa, 17 orang siswa memperoleh nilai pada range $60-89$, dan 7 siswa memperoleh nilai pada range $40-59$.

\section{c. Hasil Pengamatan (Observasi) Siklus I}

Dari tindakan Siklus I Pembelajaran 1 dan 2, diperoleh data bahwa siswa sudah mulai terlihat aktif dalam proses pembelajaran Matematika tentang operasi bilangan bulat dengan menggunakan media konkret di kelas V SD Negeri 04 Muarakuang Kabupaten Ogan Ilir Sumsel dibandingkan pada saat pertemuan pertama/tes awal. Perbandingan nilai hasil tes awal dan tindakan Siklus I sebagai berikut :

Tabel 3. Perbandingan Nilai Hasil Pengamatan Operasi bilangan bulat Pada Tes Awal dan Siklus 1

\begin{tabular}{clccc}
\hline NO & KRITERIA & $\begin{array}{c}\text { HASIL TES } \\
\text { AWAL }\end{array}$ & $\begin{array}{c}\text { HASIL } \\
\text { SIKLUS I }\end{array}$ & PENINGKATAN \\
\hline 1 & Jumlah Nilai & 1350 & 1540 & 190 \\
2 & Rata -Rata Nilai & 56 & 64 & 8 \\
3 & Persentase & 56 & 65 & 9 \\
4 & Nilai Ketuntasan & 46 & 71 & 25 \\
\hline
\end{tabular}

Untuk lebih jelas, perbandingan nilai hasil pengamatan operasi bilangan bulat pada tes awal dan siklus I, dapat ditampilkan pada diagram berikut ini.

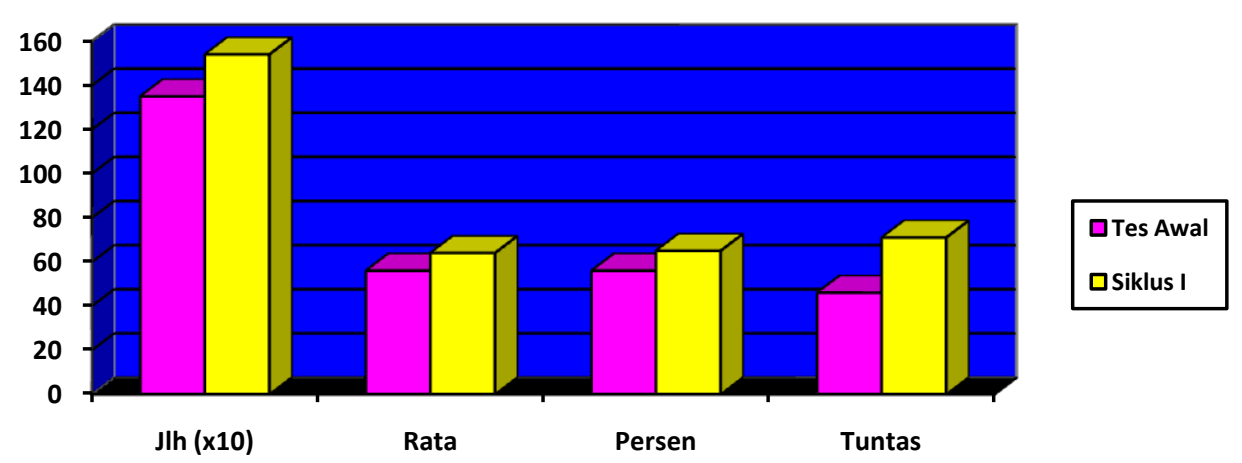

Grafik 1. Perbandingan Nilai Hasil Pengamatan Operasi bilangan bulat Pada Tes Awal dan Siklus 1

Dari tabel dan grafik di atas, dapat diketahui bahwa peneliti mengambil data dari kedua tindakan yang dilakukan berupa jumlah nilai, rata-rata, persentase dan ketuntasan. Pada jumlah nilai, terjadi peningkatan dari tes awal ke Siklus I berjumlah 190. Pada rata-rata nilai dan persentase, juga terjadi peningkatan sebesar 8 angka dari tes awal ke siklus I. Pada ketuntasan 


\section{JURNAL ILMIAH \\ BINA EDUKASI \\ ISSN 1979-8598 e-ISSN: 2655-8378 \\ http://journal.binadarma.ac.id/index.php/jurnalbinaedukasi \\ Vol. 12, No. 1, Juni 2019, 01-15}

belajar siswa, juga terjadi peningkatan dari tes awal yang hanya $46 \%$ siswa yang tuntas, menjadi $71 \%$ dengan jumlah peningkatan sebesar 25\%. Dari uraian di atas, dapat diketahui bahwa dari tindakan Siklus I, terjadi peningkatan dari hasil tes awal di semua kategori yang diambil peneliti, meskipun belum diperoleh hasil yang maksimal.

\section{a. Refleksi}

Setelah peneliti memperhatikan hasil observasi dan hasil belajar siswa pada Siklus I, dapat diambil beberapa refleksi sebagai berikut :

1. Kegiatan belajar-mengajar Matematika siswa kelas V SD Negeri 04 Muarakuang tentang operasi bilangan bulat dengan menggunakan media konkret, mengalami peningkatan.

2. Siswa lebih menyukai pembelajaran Matematika tentang operasi bilangan bulat dengan menggunakan media konkret terlebih saat guru memberikan beragam media yang akan didemontrasikan. Selanjutnya, agar siswa dapat lebih bersemangat, media konkret yang digunakan dapat ditambah jumlahnya dan mutu mediapun dapat ditingkatkan seperti variasi warna. Upaya yang dilakukan guru ini tentu akan lebih menarik minat siswa dalam keaktifan belajar.

3. Hasil belajar siswa mengalami peningkatan yang dari Tes Awal ke Siklus I. Hal ini dapat terlihat dari peningkatan jumlah nilai, rata-rata nilai, persentase dan ketuntasan siswa dalam pembelajaran Matematika tentang operasi bilangan bulat dengan menggunakan media konkret.

4. Dari hasil observasi dan hasil belajar siswa pada Siklus I, peneliti mengambil keputusan untuk melanjutkan tindakan pada tahap Siklus II. Hal ini dikarenakan masih adanya siswa yang terlihat kurang aktif dan masih minimnya siswa yang tuntas dalam pembelajaran.

\subsubsection{Hasil Penelitian Siklus II}

\section{a. Deskripsi Tindakan dan Pengamatan Siklus II Pembelajaran Ke-I}

Pelaksanaan Tindakan Siklus II Pembelajaran ke-1 pembelajaran Matematika tentang operasi bilangan bulat dengan menggunakan media konkret dilakukan pada hari Senin, tanggal 18 Februari 2019, selama 3 jam pelajaran ( 3 x 35 menit). Kegiatan ini dimulai pukul 07.30 WIB sampai pukul 09.15 WIB. Pada saat pelaksanaan tindakan Siklus I ini, jumlah siswa kelas V yang hadir berjumlah 24 orang. Berarti, semua siswa hadir dalam pembelajaran kali ini.

Ibu Purwiratnawati, S.Pd.SD adalah teman sejawat atau kolaborator dalam penelitian ini. Setelah jam pelajaran dimulai, peneliti dalam hal ini selaku guru, membariskan siswa di depan 


\section{JURNAL ILMIAH \\ BINA EDUKASI \\ ISSN 1979-8598 e-ISSN: 2655-8378 \\ http://journal.binadarma.ac.id/index.php/jurnalbinaedukasi \\ Vol. 12, No. 1, Juni 2019, 01-15}

pintu kelas, dan secara tertib masuk ke dalam kelas setelah bersalaman dengan mencium tangan guru. Setelah seluruh siswa masuk ke dalam kelas, guru menempati kursi dan meja guru yang berada di depan kelas sedangkan rekan kolaborator mengambil tempat di belakang guru selaku peneliti. Kemudian, secara tertib, siswa membaca do'a dan ayat-ayat pendek yang telah mereka hafalkan dan telah menjadi rutinitas kegiatan di awal pembelajaran. Setelah itu, guru menunjuk salah satu siswa maju ke depan kelas untuk menjadi dirigen/pemandu lagu. Kemudian guru bersama siswa menyanyikan lagu wajib Indonesia Raya, dan lagu Hymne Guru. Setelah siswa pemandu lagu kembali ke tempat duduknya, guru kemudian memberikan sedikit nasihat tentang pentingnya menghormati orang tua dan guru.

Setelah itu, guru menginstruksikan kepada siswa untuk membentuk kelompok yang terdiri dari 6 siswa per kelompoknya. Di bawah pengawasan guru, siswa secara mandiri membentuk kelompok berdasarkan posisi tempat duduk terdekat. Setelah mengondisikan kelas, memastikan kesiapan siswa dan memberikan salam pembuka pembelajaran, guru dengan didampingi kolaborator menyampaikan tujuan pembelajaran pada hari ini yaitu setelah kegiatan belajar mengajar, siswa dapat memahami tentang operasi bilangan bulat dengan menggunakan media konkret. Setelah mengucap salam dan dijawab siswa, kemudian guru bertanya kepada siswa.

Kemudian guru memerintahkan 4 siswa untuk kembali ke bangku masing-masing. Kemudian guru membagikan media yang diperlihatkan di depan kelas kepada masing-masing kelompok dan meminta siswa untuk mendemonstrasikan media. Kali ini guru memberikan tidak hanya satu media, tetapi keempat media diberikan kepada setiapkelompok. Kemudian guru menjelaskan penggunaan media konkret tersebut dalam melakukan operasi hitung bilangan bulat. Para siswa memperhatikan penjelasan dari guru. Di sela penjelasannya, guru mempersilahkan siswa untuk berdiskusi dan berbagi pemahaman dengan teman di sebelahnya dalam satu kelompok dari satu media ke media lainnya. Beberapa siswa masih terlihat berdiam diri dan hanya memperhatikan tingkah bingung sambil memegang media yang diberikan oleh guru di kelompoknya. Guru, secara aktif memberikan penjelasan dan mengawasi kegiatan penggunaan media yang dilakukan oleh siswa secara berkelompok. Guru juga terus memotivasi siswa yang mengalami kesulitan untuk berdiskusi dengan teman-teman dalam kelompoknya.

Setelah waktu demonstrasi media dan diskusi kelompok telah habis, guru kemudian memberikan kesempatan bertanya kepada masing-masing kelompok mengenai penggunaan media konkret yang baru saja mereka lakukan. Beberapa siswa mengajukan pertanyaan dan langsung dijawab oleh guru. Setelah siswa yang bertanya menyatakan jelas dan para siswa lain pun jelas, guru beranjak pada pertanyaan siswa selanjutnya. Di sela-sela kegiatan, ada beberapa 


\section{JURNAL ILMIAH}

BINA EDUKASI

ISSN 1979-8598 e-ISSN: 2655-8378

http://journal.binadarma.ac.id/index.php/jurnalbinaedukasi

Vol. 12, No. 1, Juni 2019, 01-15

siswa yang permisi kepada guru untuk ke kamar kecil dan dipersilahkan oleh guru secara bergantian.

Pada penghujung jam pelajaran, guru dengan pengawasan teman sejawat meminta siswa untuk mencatat beberapa poin-poin penting tentang pembelajaran yang baru saja dilaksanakan. Setelah itu, guru menyimpulkan pembelajaran hari ini dan menjelaskan rancangan kegiatan pada pertemuan selanjutnya. Pada kegiatan siklus II pembelajaran I ini, tidak dilakukan tes dan direncsiswaan akan dilakukan pada pembelajaran selanjutnya yaitu pada Siklus II pembelajaran ke - II.

\section{b. Deskripsi Tindakan dan Pengamatan Siklus II Pembelajaran Ke-II}

Pada Kegiatan pelaksanaan pembelajaran ke-II pembelajaran Matematika tentang operasi bilangan bulat dengan menggunakan media konkret dilakukan pada hari Kamis, tanggal 21 Februari 2019 selama 3 jam pelajaran (3 x 35 menit). Kegiatan ini dimulai pukul 07.30 WIB sampai pukul 09.15 WIB. Pada saat pelaksanaan tindakan Siklus II ini, jumlah siswa kelas V yang hadir tetap berjumlah 24 orang. Artinya seluruh siswa tetap hadir total.

Perolehan data diketahui bahwa dari 24 siswa, 21 berhasil mencapai nilai KKM. Artinya ketuntasan yang dicapai pada Siklus I adalah $86 \%$.

Lebih lanjut, hasil nilai Siklus II berdasarkan nilai tertinggi, terendah dan rata-rata diketahui pada tabel berikut :

Tabel 4. Nilai Hasil Siklus II tentang Operasi Bilangan Bulat

\begin{tabular}{cccccc}
\hline No & Nilai & Frekuensi & Tertinggi & Terendah & Rata-Rata \\
\hline 1 & $90-100$ & 9 & & & \\
2 & $60-89$ & 12 & & & \\
3 & $40-59$ & 3 & 100 & & \\
4 & $20-39$ & 0 & & & \\
5 & $0-19$ & 0 & $\mathbf{2 4}$ & & \\
& Jumlah & &
\end{tabular}

Dari tabel di atas, diketahui bahwa nilai tertinggi dari Siklus II adalah 100 dan nilai terendah adalah 50 dengan rata-rata 76 . Dari 24 siswa, 3 orang memperoleh nilai pada range no. 3, 12 orang siswa memperoleh nilai pada range $60-89$, dan 9 siswa memperoleh nilai pada range $90-100$. 


\section{JURNAL ILMIAH}

BINA EDUKASI

ISSN 1979-8598 e-ISSN: $2655-8378$

http://journal.binadarma.ac.id/index.php/jurnalbinaedukasi

Vol. 12, No. 1, Juni 2019, 01-15

\section{Hasil Pengamatan (Observasi) Siklus II}

Dari tindakan Siklus II Pembelajaran 1 dan 2, diperoleh data bahwa secara keseluruhan siswa sudah terlihat aktif dalam proses pembelajaran Matematika tentang operasi bilangan bulat dengan menggunakan media konkret di kelas V SD Negeri 04 Muarakuang Kabupaten Ogan Ilir Sumsel dibandingkan saat pertemuan pada Siklus I, terlebih pada tes awal.

Siswa antusias mengikuti pelajaran. Keterlibatan siswa lebih tampak setelah guru memberikan seluruh jenis media konkret kepada setiap kelompok.

Berdasarkan pengamatan, keaktifan siswa-siswi bertambah. Ini terlihat komunikasi antar siswa dalam kelompok dan antara kelompok sama-sama punya pendapat. Siswa dengan cepat merespons instruksi dari guru. Kondisi kelas saat itu begitu aktif dan harmonis tetapi tetap terkendali sehingga proses pembelajaran berjalan dengan cukup baik. Pada pembelajaran Siklus II ini, tidak ada lagi siswa yang pasif dalam mengikuti pembelajaran dan sudah banyak siswa berani dalam menanggapi hasil kerja kelompoknya dan mengemukakan pendapat apabila ditemukan kekurangsempurnaan proses dan hasil kerja. Perbandingan nilai hasil tindakan siklus II dan siklus I sebagai berikut.

Tabel 5. Perbandingan Nilai Hasil Pengamatan Operasi Bilangan Bulat pada Siklus I dan Siklus II

\begin{tabular}{clrrr}
\hline NO & KRITERIA & HASIL & $\begin{array}{c}\text { HASIL } \\
\text { SIKLUS II }\end{array}$ & PENINGKATAN \\
\hline 1 & Jumlah Nilai & 1540 & 1830 & 290 \\
2 & Rata -Rata Nilai & 64 & 76 & 12 \\
3 & Persentase & 65 & 79 & 14 \\
4 & Nilai Ketuntasan & 71 & 86 & 15 \\
\hline
\end{tabular}

Untuk lebih jelas, perbandingan nilai hasil pengamatan operasi bilangan bulat pada siklus I dan siklus II, dapat ditampilkan pada grafik berikut ini :

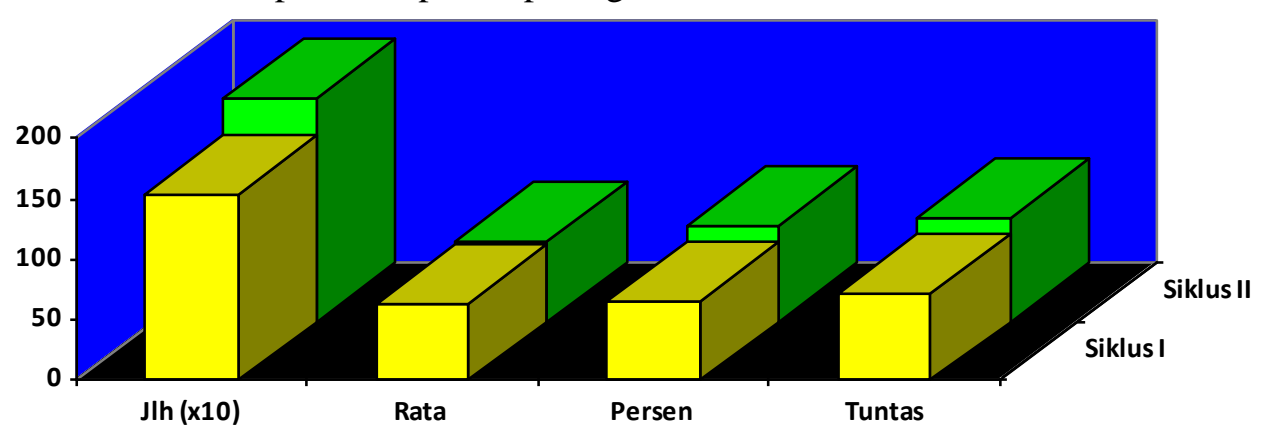

Grafik 2. Perbandingan Nilai Hasil Pengamatan Operasi Bilangan Bulat pada Siklus I dan Siklus II 


\section{JURNAL ILMIAH \\ BINA EDUKASI \\ ISSN 1979-8598 e-ISSN: 2655-8378 \\ http://journal.binadarma.ac.id/index.php/jurnalbinaedukasi \\ Vol. 12, No. 1, Juni 2019, 01-15}

Dari tabel dan grafik di atas, dapat diketahui bahwa peneliti mengambil data dari kedua tindakan yang dilakukan berupa jumlah nilai, rata-rata, persentase dan ketuntasan. Pada jumlah nilai, terjadi peningkatan dari siklus I ke siklus II berjumlah 290. Pada rata-rata nilai dan persentase, juga terjadi peningkatan sebesar 12 angka dari tindakan Siklus I ke Siklus II. Pada ketuntasan belajar siswa, juga terjadi peningkatan dari Siklus I yang hanya $71 \%$ siswa yang tuntas, menjadi $86 \%$ dengan jumlah peningkatan sebesar 15\%. Dari uraian di atas, dapat diketahui bahwa dari tindakan Siklus II, terjadi peningkatan yang sangat signifikan dari hasil Siklus I di semua kategori yang diambil peneliti.

\section{d. Refleksi}

Setelah peneliti memperhatikan hasil observasi dan hasil belajar siswa pada Siklus II, dapat diambil beberapa refleksi sebagai berikut :

1. Kegiatan belajar-mengajar matematika siswa kelas V SD Negeri 04 Muarakuang tentang operasi bilangan bulat dengan menggunakan media konkret, mengalami peningkatan yang sangat signifikan. Hal ini dapat dilihat dari data deskripsi aktivitas siswa yang terlihat lebih aktif dan antusias. Nyaris tidak ditemukan siswa yang kurang aktif baik dalam kegiatan kelompok maupun dalam mengikuti kegiatan belajar mengajar yang terapkan guru.

2. Dengan pembelajaran menggunakan media konkret dan strategi belajar moderat, siswa lebih menyukai pembelajaran Matematika tentang operasi bilangan bulat terlebih saat guru membagikan semua jenis media kepada setiap kelompok.

3. Hasil belajar siswa mengalami peningkatan yang cukup signifikan dari Siklus I ke Siklus II. Hal ini dapat terlihat dari peningkatan jumlah nilai, rata-rata nilai, persentase dan ketuntasan siswa dalam pembelajaran Matematika tentang operasi bilangan bulat dengan menggunakan media konkret yang dipelajari siswa kelas V SD Negeri 04 Muarakuang.

4. Dari data hasil tindakan yang dilakukan pada siklus II, peneliti mengambil keputusan untuk menyelesaikan tindakan penelitian dan tidak perlu melanjutkan penelitian pada tahap Siklus III dikarenakan pemenuhan $86 \%$ atas KKM.

\subsection{PEMBAHASAN}

Dari hasil pengamatan yang telah dilaksanakan, pada Siklus I menunjukkan hasil yang positif, yaitu adanya peningkatan proses dan hasil belajar siswa dibandingkan pada tes awal. Hasil positif ini juga tampak pada Siklus II. Seiring dengan hasil Siklus I, data Siklus II juga menunjukkan peningkatan. Dari 4 kriteria yang diambil peneliti, yakni jumlah nilai, rata-rata, 


\section{JURNAL ILMIAH}

BINA EDUKASI

ISSN 1979-8598 e-ISSN: $2655-8378$

http://journal.binadarma.ac.id/index.php/jurnalbinaedukasi

Vol. 12, No. 1, Juni 2019, 01-15

persentase dan ketuntasan, seluruhnya menunjukkan grafik yang menanjak. Grafik 3, memperlihatkan peningkatan nilai dari Tes Awal, Siklus I dan Siklus II sebagai berikut :
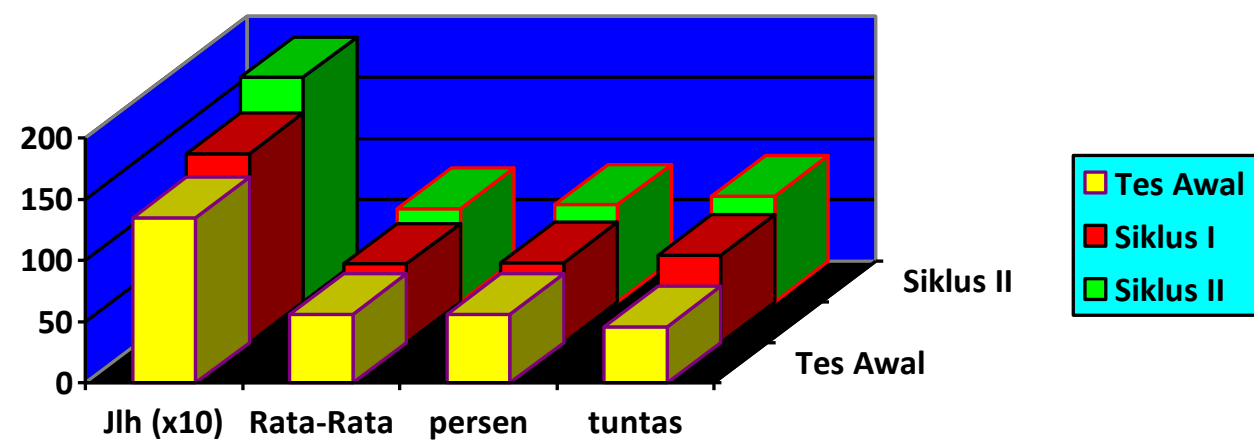

Grafik 3. Peningkatan Hasil Tes Awal, Siklus I dan Siklus II tentang Operasi Bilangan Bulat

Dari data yang ditampilkan oleh Grafik di atas, menunjukkan bahwa penerapan media konkret dalam kegiatan belajar mengajar Matematika tentang operasi bilangan bulat, telah berhasil dilakssiswaan dan mendapatkan hasil yang sesuai harapan peneliti. Artinya, media yang diterapkan sudah lebih tepat sasaran.

Ketepatan penggunaan media konkret dalam pembelajaran matematika ini selaras dengan pendapat Bruner dalam Aisyah (2007), yang menyatakan bahwa dalam kegiatan belajar mengajar dengan materi penelusuran jalur operasional bilangan, media konkret dapat lebih tepat digunakan dan lebih antusias disambut siswa. Dalam hal ketuntasan misalnya, di Grafik 3, terlihat ketuntasan belajar siswa (KKM) meningkat dari Tes Awal yang berjumlah 46\%, pada Siklus I menjadi $71 \%$ dan jumlah Siklus II lebih tinggi menjadi $86 \%$. Data ini juga berbanding lurus dengan jumlah, rata-rata, dan persentase nilai hasil belajar siswa.

Dalam kurva 1, ditampilkan peningkatan hasil belajar siswa dari 4 elemen yang diamati oleh peneliti:

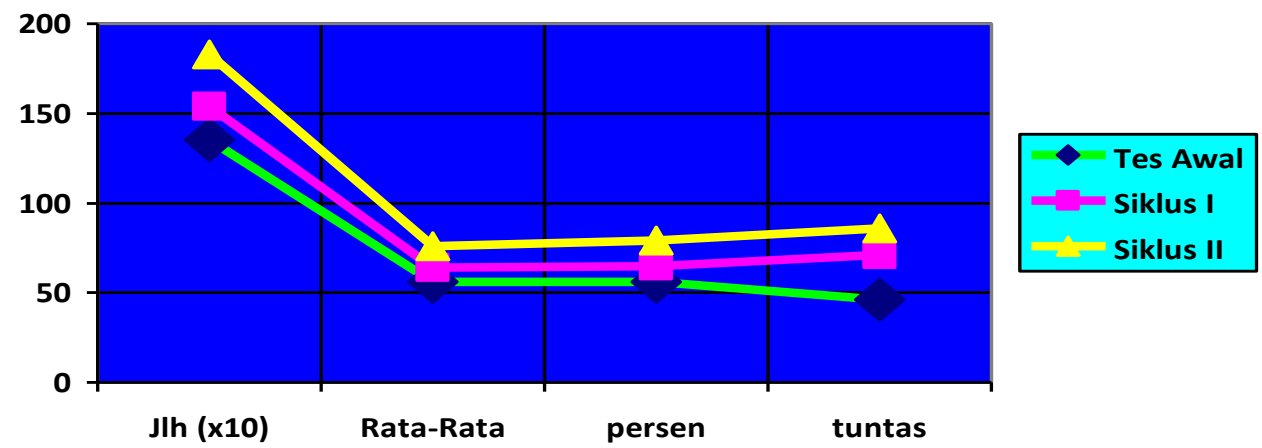

Kurva 1. Peningkatan Hasil Tes Awal, Siklus I dan Siklus II tentang Operasi Bilangan Bulat 


\section{JURNAL ILMIAH}

BINA EDUKASI

ISSN 1979-8598 e-ISSN: 2655-8378

http://journal.binadarma.ac.id/index.php/jurnalbinaedukasi

Vol. 12, No. 1, Juni 2019, 01-15

Dengan diperolehnya ketuntasan pada Siklus II sebesar 86\%, maka peneliti merasa tidak perlu melanjutkan pengamatan pada tindakan Siklus III karena telah diperoleh ketuntasan belajar sesuai harapan.

\section{SIMPULAN}

Dari kegiatan penelitian tindakan kelas dalam upaya meningkatkan hasil belajar Matematika tentang operasi bilangan bulat dengan menggunakan media konkret, siswa kelas $\mathrm{V}$ SD Negeri 04 Muarakuang ini, dapat ditarik kesimpulan sebagai berikut :

1. Penerapan media konkret dapat meningkatkan hasil belajar siswa tentang operasi bilangan bulat. Hal ini diperlihatkan dari peningkatan data beberapa kategori (jumlah, rata-rata, persentase keberhasilan dan ketuntasan siswa mencapai KKM) yang diambil peneliti di tiga tahap tindakan yaitu pada Tes Awal, Siklus I dan Siklus II.

2. Guru dalam hal ini peneliti, sudah menerapkan strategi pembelajaran dan media dengan tepat. Hal ini dapat dilihat dari peningkatan antusias dan hasil belajar siswa.

3. Dengan penerapan media konkret yang sederhana namun tetap relevan dan bermutu, dapat menarik perhatian siswa untuk tetap fokus mengikuti proses pembelajaran, termasuk melakukan pengamatan dan mengerjakan tugas, instruksi dan tes dari guru.

4. Dengan adanya metode, strategi dan kemampuan pengelolaan kelas dengan baik, dapat diperoleh hasil belajar yang lebih maksimal, termasuk pelajaran matematika tentang operasi bilangan bulat siswa kelas V SD Negeri 04 Muarakuang.

\section{DAFTAR PUSTAKA}

Aisyah Siti, dkk. (2007). Perkembangan dan Konsep Dasar Perkembangan Siswa Usia Dini. Jakarta : Universitas Terbuka.

Arikunto, Suharsimi. (2010). Prosedur Penelitian Suatu Pendekatan Praktik Edisi Revisi VI. Jakarta: PT Rineka Cipta.

Depdiknas, (2004). Pedoman Pengembangan Silabus, Jakarta.

Iskandar, Dadang dan Narsim. (2015). Penelitian Tindakan Kelas dan Publikasinya. Cilacap: Ihya Media.

Novikasari, Ifada dan Mutijah. (2010). Geometri dan Pengukuran. Purwokerto: STAIN

Purwokerto PressKurt Lewis dalam Rochiati, 2006 


\section{JURNAL ILMIAH}

BINA EDUKASI

ISSN 1979-8598 e-ISSN: $2655-8378$

http://journal.binadarma.ac.id/index.php/jurnalbinaedukasi

Vol. 12, No. 1, Juni 2019, 01-15

Pujiati, (2004). Penggunaan Alat Peraga dalam Pembelajaran Berhitung di SD, Jogjakarta: PPPG JOGJAKARTA.

Samidi \& Puspitasari, T. (2004). Bahasa Indonesia untuk SD/MI Kelas III. Jakarta: Pusat

Perbukuan Departemen Pendidikan Nasional.

Sanjaya, Wina. (2011). Strategi Pembelajaran Berorientasi Standar Proses Pendidikan. Jakarta: Kencana.Setiadi, M., Elly. dkk. 2012. Ilmu Sosial Budaya Dasar. Jakarta: Prenada Media Group.

Sugiyono. (2010). Metode Penelitian Pendidikan Pendekatan Kuantitatif, Kualitatif, dan R\&D. Bandung: Alfabetapendapat

Winataputra. (2005). "Revisi Taksonomi Bloom Ranah Kognitif”. (online), (http://kamriantiramli.wordpress.com/2011/04/21/; diakses 29 Desember 2011). 